\title{
Harvesting techniques for non-industrial SRF biomass plantations on farmland
}

\author{
Raffaele Spinelli, ${ }^{1}$ Janine Schweier, ${ }^{2}$ Fabio De Francesco, ${ }^{1}$ \\ ${ }^{1}$ CNR IVALSA, Sesto Fiorentino (FI), Italy; ${ }^{2}$ Institute of forest utilisation and work science, \\ Alberts-Ludwigs-University, Freiburg i. B., Germany
}

\begin{abstract}
The goal of this study was to compare the technical and economic performance of terrain chipping and roadside chipping, applied to short rotation biomass plantations. The null hypothesis was that no significant difference are in the performance of the two work systems, when applied to short rotation coppices. Those systems especially designed for non-industrial SRF plantations, were used for conventional logging operations. The difference on the above mentioned systems consisted especially in the chipping location: chipping was performed directly to the field (containers reach the chipper in the field) or at the field's edge (roadside chipping). Both systems were tested on two of the most common SRF poplar clones in Italy, namely: AF2 and Monviso. Plots were allocated randomly to the two treatment levels (roadside or field chipping) than blocked for two main clone types ( AF2 and Monviso ) so that each of the 4 treatments level and clone types has a minimum repetition plot of 6 times (total of 24 replications). The Plot were identified with paint markings at the stump so each plot area could be identified at the ground. Net weight of each charge was obtained by a certified weighbridge, so each plot has its own productivity in terms of weight and time consumption. Results were encouraging: harvesting cost varied from 16.3 to $23.2 €$ tonne-1, and was lower for terrain chipping and for the most productive clone (Monviso). Despite its higher cost, roadside chipping was preferred for its better terrain capability and for the superior storage quality of uncomminuted biomass. Both systems were suboptimal in their current configurations. They could offer a better performance, subject to minor improvements
\end{abstract}

Correspondence: Raffaele Spinelli, CNR IVALSA via Madonna del Piano 10 Sesto Fiorentino (FI), Italy.

Tel.+39.055.5225641 - Fax+39.055.5225643.

E-mail: spinelli@ivalsa.cnr.it

Key words: poplar, mechanization, CTL.

Acknowledgements: Support for this study was provided by Pellerei - Ago AG and by COST Action FP0902 within the scope of its 4th STSM programme.

CC Copyright R. Spinelli et al., 2013

Licensee PAGEPress, Italy

Journal of Agricultural Engineering 2013; XLIV(s2):e2

doi:10.4081/jae.2013.s2.e2

This article is distributed under the terms of the Creative Commons Attribution Noncommercial License (by-nc 3.0) which permits any noncommercial use, distribution, and reproduction in any medium, provided the original author(s) and source are credited.

\section{Introduction}

Covering marginal farmland with fast-growing tree species could be a cost-effective way to produce wood biomass for industrial and energy use (Hoogwijk et al. 2003). Afforestation, compared to conventional agriculture, offers a better environmental performance due to reduced water (Heller et al. 2003), chemical (Sage 1998) and fossil energy (Djomo et al. 2011, Hillier et al. 2009) inputs. In case of soil and groundwater contamination, planting trees can be a way to filter it (Rockwood et al. 2004). After changing land use from farm crops to forest plantations the soil carbon stock increases (Guo and Gifford 2002, Coleman et al. 2004) and the farm-scale biodiversity and landscape are also improved (Rowe et al. 2011, Weih 2008).

Depending on site conditions and product strategy, modern biomass plantations have a harvesting turnover from 2 to 10 years if established with hardwoods (O'Neill et al. 2010). Farmers prefer a very short rotations ( 2 to 4 years) because they are used to short return times and are generally averse to long waiting times (Londo et al. 2004). Due to the small tree size, 2 to 4 years turnover plantations are effectively harvested with modified foragers (Manzone et al. 2009). In contrast, bigger investors can afford longer return times and favour slightly longer rotations (5 to 10 years), which generally offer better value recovery (Spinelli et al. 2008). These plantations are best harvested with dedicated forest technology, specifically modified for the task (Spinelli and Hartsough 2006, Grosse et al. 2008). Many benefits are offered by a rotation between 5 and 10 years because a better capacity to capture growth rate increase as the longer turnover, (Ceulemans and Deraedt 1999; Pallardy et al. 2003); a higher resiliency to the effects of the occasional bad season (Badenau and Auclair 1989); the capacity of guaranteeing high biomass yields at lower planting densities (Willebrand $e t$ al. 1993); a lower bark to fibre ratio (Phelps et al. 1985), offering higher pulp (Ai and Tschirner 2010) or energy conversion (Kenney et al. 1990) yields, as well as lower ash contents (Tharakan et al. 2003). The advantages of extended rotations have finally attracted European farmers (Spinelli et al. 2011), who seem increasingly disaffected with traditional short rotation coppice (Helby et al. 2006).

However, extended rotations offer relatively large trees, which cannot be harvested with adapted foragers (Spinelli et al. 2009a). Unfortunately, most farmers lack the critical mass to acquire highlyproductive forestry equipment, just for harvesting their own biomass plantations. Hence, there is a need for adapting conventional forest machinery to use in the new crops. In Europe, that means using cutto-length (CTL) equipment, especially harvesters and forwarders (Gellerstedt \& Dahlin 1999). These machines are designed for felling, delimbing and crosscutting trees directly at the stump site, and then forwarding processed assortments to the nearest landing (Chiorescu and Grönlund 2001). Harvesters and forwarders are not designed for whole-tree harvesting, which has proven the most effective system when handling biomass plantations (Spinelli et al. 2009b). However, they can still be used for whole-tree harvesting, although with a some- 
what reduced efficiency. The goal of this study was to determine the performance of conventional CTL equipment when used for whole-tree harvesting in biomass plantations. In particular, we determined the unit harvesting cost in financial, energy and emission terms. Suggestions for improvement were also provided.

\section{Materials}

The machines used to make this study were a dedicated harvester (Valmet 921), a 10-t forwarder (Valmet 840), an industrial $335 \mathrm{~kW}$ chipper (Jenz HEM 561) towed by a $95 \mathrm{~kW}$ farm tractor (Valtra 8450) and two tractor-trailer units which have a capacity of $42 \mathrm{~m}^{3}$. the chips load was moved from the field to the central collection point consisting in a concrete pad, covering a distance of $600 \mathrm{~m}$. The access at the fields is possible only if the soil was not wet. The system was like the type commonly used for the harvesting of conventional poplar plantations (Spinelli et al. 2011b).

The system was tested in two different configuration: in the first configuration called "field's edge" trees were felled and bunched by the harvester and then crosscut at mid-length with a chainsaw, than the 10-t forwarder moved the tree sections to the chipper at field's edge, over an average distance of $150 \mathrm{~m}$. Chips were blown into the two tractor-trailer units, and transported to the central collection point.

The second configuration, called "terrain chipping", trees were felled and bunched by the harvester, then reached by the chipper directly in the field, so that neither crosscutting nor separate forwarding were necessary, because the same tractor-trailer units moved the chips from the field to the central collection point. This mode was swifter, because required fewer steps, but could only be applied if the field was accessible to the heavy chipper and the cumbersome tractor-trailer units. It was also least suited to building long-term biomass stores, which should be assembled with tree sections rather than chips, because chips do not store well (Jirijs 2005).

This system was tested on two different poplar clones, among the most common in Italian poplar plantations. These were the hybrid poplar (Populus x euroamericana) clones AF2 and Monviso.

\section{Methods}

The experimental design included four treatments, deriving from the combination of clone types (AF2 or Monviso) with harvest modes (terrain chipping or roadside chipping). Each treatment was replicated 6 times. Therefore, the plantations were divided into experimental blocks consisting of 4 rows of 25 trees each. Since the trees had been established at a $3 ¥ 2 \mathrm{~m}$ spacing the average surface area of the plots was equal to $600 \mathrm{~m}^{2}$. The blocks were located in two adjacent 5 -year-old plantations and were randomly assigned to the harvesting modes in each plantation (Figure 1).

The authors recorded the time spent on each block by each machine, separating productive time from delay time (Björheden et al. 1995). Delay time is typically erratic, and it may introduce excessive variability to a study conducted on relatively small blocks. Besides, a short-term study may fail to produce an accurate representation of delay time. For this reason, delay time was averaged for each machine across the whole test (i.e. 12 blocks for the chainsaw and the forwarder and 24 blocks for the harvester and the chipper). Hence, the total net time and delay time for each machine were used to calculate an appropriate delay factor, i.e. the ratio of delay time to net work time. Delay factors were then compared to the results obtained from other long term stud- ies, conducted by the same authors on the same machine types under similar work conditions (Spinelli et al. 2003, Spinelli and Visser 2008, Spinelli and Visser 2009). Corroboration was obtained for the harvester, the chainsaw and the forwarder, whose measured delay factors were adopted into use. The delay factor calculated for the chipper was not corroborated by existing literature, and was discarded. Instead, we adopted the long-term figures found in the reference material.

Harvested volumes were estimated by taking all chip loads to a certified weighbridge. Loads were separated by block, assembling partial loads when necessary. Moisture content determination was conducted on 6 samples per clone, collected in sealed bags and weighed fresh and after drying for 48 hours at a temperature of $103^{\circ} \mathrm{C}$ in a ventilated oven.

Machine costs were provided by the contractor and reflected the contracting rates typical of the region. They were: $110 € \mathrm{~h}^{-1}$ for the harvester, $15 € \mathrm{~h}^{-1}$ for the chainsaw team, $70 € \mathrm{~h}^{-1}$ for the forwarder, 240 $€ \mathrm{~h}^{-1}$ for the chipper and $50 € \mathrm{~h}^{-1}$ for each tractor-trailer unit. In fact, when chipping was performed at roadside, one driver managed both tractor-trailer units, so that the total cost for the two units dropped from $100 € \mathrm{~h}^{-1}$ to $75 € \mathrm{~h}^{-1}$.

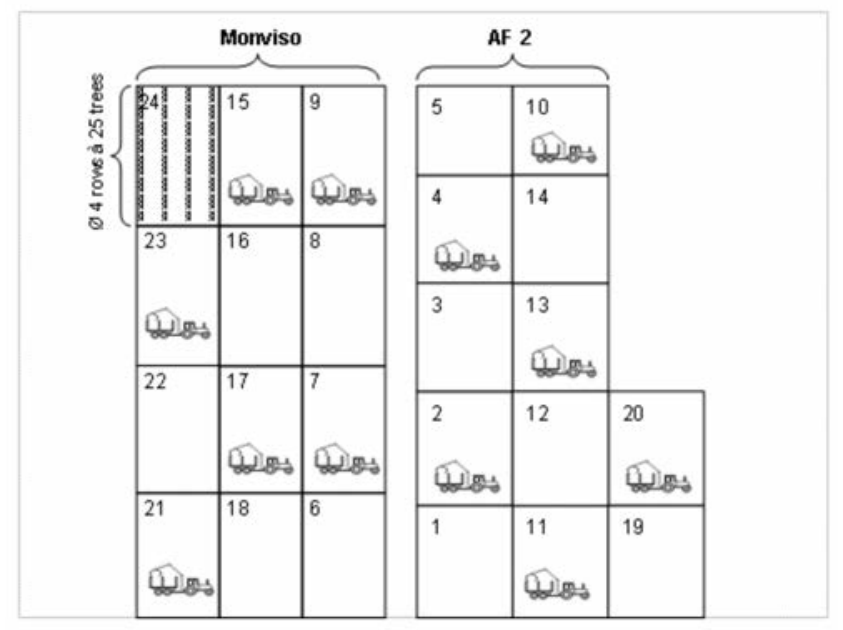

Figure 1. Experiment layout.

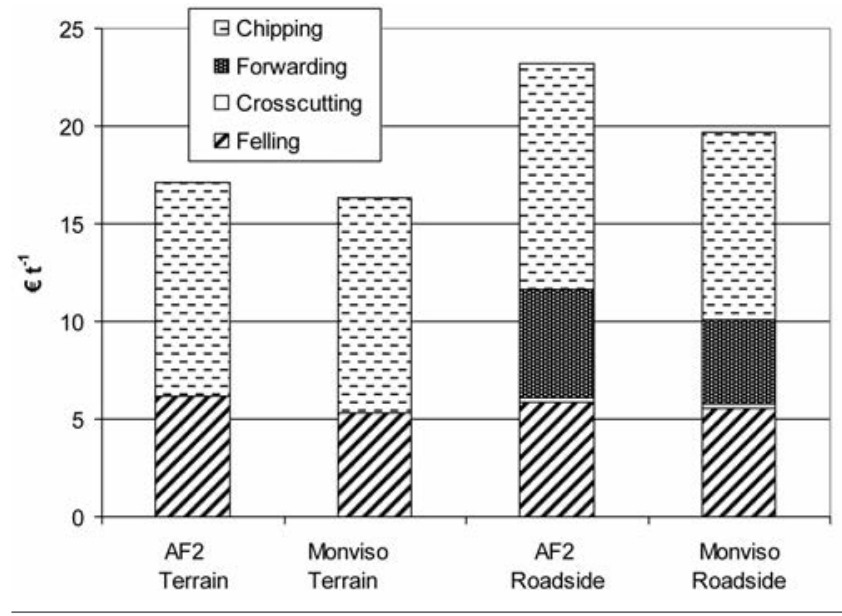

Figure 2. Breakdown of harvest cost by work step. 


\section{Results and Discussion}

Both clones performed very well, with a high survival rate and a very fast growth: Monviso gave the best results, offering larger tree size and higher stand stocking compared to AF2. All these differences were statistically significant. Monviso trees had a significantly smaller diameter at breast-height compared to AF2 trees. They were also taller, but in this case the difference had no statistical significance. The same accounted for moisture content. Hence, the larger individual weight of Monviso trees must be related to different form, taper or branching. Table 1 shows the basic statistics for the test fields.

Table 1. Stand characteristics and biomass yield by harvesting site.

\begin{tabular}{|c|c|c|c|c|c|}
\hline \multirow[t]{2}{*}{ Clone type } & \multicolumn{2}{|c|}{ AF2 } & \multicolumn{2}{|c|}{ Monviso } & \multirow[t]{2}{*}{$P$} \\
\hline & mean & SD & mean & SD & \\
\hline $\mathrm{DBH}, \mathrm{cm}$ & 16.2 & 0.7 & 14.6 & 0.8 & $<0.0001$ \\
\hline Height, m & 18.2 & 2.3 & 18.7 & 1.8 & 0.7569 \\
\hline Mass, kg tree $e^{-1}$ & 116.8 & 12.3 & 125.5 & 10 & 0.0713 \\
\hline Density, trees ha ${ }^{-1}$ & 1595.1 & 33.9 & 1599.8 & 20.7 & 0.6891 \\
\hline Stocking, tonnes ha- ${ }^{-1}$ & 186.3 & 19.3 & 200.9 & 17.8 & 0.0669 \\
\hline m.c., $\%$ & 56.3 & 1.7 & 54.7 & 1.2 & 0.0839 \\
\hline Stocking, odt ha-1 & 81.4 & 8.4 & 91 & 8.1 & 0.0093 \\
\hline Yield, odt ha ${ }^{-1}$ year $^{-1}$ & 16.3 & 1.7 & 18.2 & 1.6 & 0.0093 \\
\hline
\end{tabular}

$\mathrm{DBH}=$ tree diameter at breast height; $\mathrm{SD}=$ standard deviation; odt $=$ oven-dry tonnes; $\mathrm{P}=\mathrm{p}$-value for the clonal difference obtained from the unpaired $t$-test; Density = tree density at harvest, from a theoretical initial density of 1667 trees ha-1.

Table 2. Machine productivity by clone type and harvest mode.

\begin{tabular}{lcccc} 
Clone type & $\begin{array}{c}\text { Harvest mode } \\
\text { AF2 }\end{array}$ & $\begin{array}{c}\text { Terrain chipping } \\
\text { Monviso }\end{array}$ & $\begin{array}{c}\text { Roadside chipping } \\
\text { AF2 }\end{array}$ & $\begin{array}{l}\text { Monviso } \\
\text { Felling }\end{array}$ \\
Crosscutting & 18.0 & 21.1 & 18.9 & 20.2 \\
\hline Forwarding & NA & NA & 58.3 & 59.5 \\
Chipping & 31.2 & NA & 12.9 & 16.4 \\
\hline
\end{tabular}

Productivity figures are in fresh tonnes per scheduled work hour, including delays.
Average yield was 18.2 and 16.3 oven-dry tonnes (odt) per ha, respectively for Monviso and AF2. These figures compared well with the average values measured further north for the best poplar (Karacic et al. 2003; Pellis et al. 2004; Henderson and Jose 2010) and willow (Nordh and Verwjist 2004, Proe et al. 2002) clones. This was a witness to the good quality of the Italian clones and climate. In this respect, it is important to note that the values in this study were net, after harvesting losses, and they were obtained from relatively large plots under operational conditions. As is shown in Table 2 and in Table 3 (ANOVA), the productivity of felling, forwarding and chipping was significantly affected by clone type (Monviso or AF2. The effect of clone type is explained by the different tree size, which has a strong impact, on the other hand, harvest mode (i.e. terrain chipping or roadside chipping) doesn't affect machine productivity. That has been demonstrated many times for harvesters (Holtzscher et al. 1997), feller-bunchers (Visser and Stampfer 2003), forwarders (Tiernan et al. 2004) and chippers (Spinelli and Magagnotti 2010). The lack of any significant effect for harvest mode points at the versatile quality of the machines on test. It may also hint at a suboptimal system, which is not specialised enough for deployment under specific mode and conditions. This point is supported by the superior productivity figures obtained with specialised harvesting systems. Under the very similar conditions of US poplar plantations, the productivities of felling, forwarding and chipping are $35 \div 45,30 \div 45$ and $48 \div 52$ t hour $^{-1}$, respectively (Spinelli and Hartsough 2006). These values are between 1.4 and 2.7 times higher than those obtained from the current experiment. Similar differences are also found for the whole-tree harvesting of eucalypt trees from SRF plantations (Spinelli et al. 2009b). The differences are highest for felling and forwarding, which should receive priority when trying to improve the harvesting system under test. Significant improvements could be obtained with limited investment. In particular, the harvester head on the dedicated CTL harvester should be replaced with an accumulating felling-bunching device, capable of multi-tree handling. Specific models are now available for application to conventional CTL harvesters, and can be obtained at a reasonable price (Spinelli et al. 2006). On the forwarder, the conventional short-wood bunk should be replaced with an inverted grapple for temporary conversion into a clam-bunk skidder. This machine is best suited to whole-tree extraction, and would offer superior productivity. Both measures would not require large investments and would be reversible. Hence, they could be implemented by small contractors and would maintain the versatile character of existing machinery, which could be reconverted to the old configuration for use in conventional forestry operations.

Table 3. Anova table for machine productivity

\begin{tabular}{|c|c|c|c|c|c|c|c|}
\hline & Effect & DF & SS & MS & F-Value & P-Value & Power \\
\hline Felling & $\begin{array}{l}\text { Treatment } \\
\text { Clone } \\
\text { Interaction } \\
\text { Residual }\end{array}$ & $\begin{array}{c}1 \\
1 \\
1 \\
20\end{array}$ & $\begin{array}{c}1.24^{*} 10^{-5} \\
29.03 \\
5.35 \\
87.42\end{array}$ & $\begin{array}{c}1.24 * 10-5 \\
29.03 \\
5.35 \\
4.37\end{array}$ & $\begin{array}{c}3.27 * 10^{-6} \\
6.64 \\
1.23\end{array}$ & $\begin{array}{l}0.9986 \\
0.0180 \\
0.2816\end{array}$ & $\begin{array}{l}0.05 \\
0.69 \\
0.18\end{array}$ \\
\hline Crosscutting & $\begin{array}{l}\text { Clone } \\
\text { Residual }\end{array}$ & $\begin{array}{c}1 \\
10 \\
\end{array}$ & $\begin{array}{c}4.61 \\
1677.17\end{array}$ & $\begin{array}{c}5.61 \\
167.72 \\
\end{array}$ & 0.03 & 0.8716 & 0.05 \\
\hline Forwarding & $\begin{array}{l}\text { Clone } \\
\text { Residual }\end{array}$ & $\begin{array}{c}1 \\
10\end{array}$ & $\begin{array}{l}35.26 \\
32.12\end{array}$ & $\begin{array}{c}35.26 \\
3.21\end{array}$ & 10.98 & 0.0078 & 0.86 \\
\hline Chipping & $\begin{array}{l}\text { Treatment } \\
\text { Clone } \\
\text { Interaction } \\
\text { Residual }\end{array}$ & $\begin{array}{c}1 \\
1 \\
1 \\
20\end{array}$ & $\begin{array}{c}0.14 \\
50.85 \\
55.84 \\
222.71\end{array}$ & $\begin{array}{c}0.14 \\
50.85 \\
55.84 \\
11.14 \\
\end{array}$ & $\begin{array}{l}0.01 \\
4.57 \\
5.01\end{array}$ & $\begin{array}{l}0.9105 \\
0.0452 \\
0.0367\end{array}$ & $\begin{array}{l}0.05 \\
0.52 \\
0.56\end{array}$ \\
\hline
\end{tabular}


Table 4. Harvesting cost: financial.

\begin{tabular}{lcccc}
$\begin{array}{l}\text { Harvest mode } \\
\text { Clone type }\end{array}$ & TF2 & Terrain chipping & Roadside chipping & Monviso \\
Financial $\left(€ \mathrm{t}^{-1}\right)$ & 17.1 & 16.3 & 23.2 & 19.7 \\
\hline
\end{tabular}

Table 5.Anova table for the financial, energy and emission cost.

\begin{tabular}{llcccccc}
\multicolumn{1}{c}{ Effect } & DF & SS & MS & F-Value & P-Value \\
Financial & Treatment & 1 & 133.46 & 133.46 & 63.51 & $<0.0001$ & 0.0018 \\
& Clone & 1 & 27.30 & 27.30 & 12.99 & 0.94 \\
& Interaction & 1 & 10.83 & 10.83 & 5.15 & 0.0344 & 0.57 \\
& Residual & 20 & 42.03 & 2.10 & & \\
\hline
\end{tabular}

The monetary cost of harvesting varied between 16.3 and $23.2 € \mathrm{t}^{-1}$, delivered to the central collection point and excluding further transportation (Table 4). Both clone type and harvest mode had a significant effect on unit cost (Table 5): cost was lower for the Monviso clone, due to its larger tree size; it was higher for roadside chipping, due to the larger number of work steps, each incurring additional expenses (Figure 2). These costs are relatively high, if compared to the costs reported for the industrial harvesting of the US poplar plantations, in the range of 10 US dollars per tonne. The costs recorded in this study were also higher than those reported for harvesting shorter rotations with forage harvesters, which are in the range of $15-20 € \mathrm{t}^{-1}$ (Spinelli et al. 2009a). However, the costs recorded in this study are still much below the average price offered by most industrial biomass plants in Italy. This is estimated to $48 € \mathrm{t}^{-1}$ delivered to the plant (Spinelli et al. 2011c), which leaves between 15 and $22 € \mathrm{t}^{-1}$ to cover plantation costs, after deducting an average transportation cost around $10 € \mathrm{t}^{-1}$.

\section{Conclusions}

Conventional forest machinery can be easily deployed for harvesting biomass plantations established over farmland.

The harvesting system offers a suboptimal performance, but it can be substantially improved, especially when deployed under the roadside chipping mode. This could allow a significant reduction of harvesting cost, for a relatively small additional investment. While terrain chipping incurs the lowest harvesting cost, it may be safest to focus on roadside chipping. This has a higher potential for improvement and offers significant technical advantages. In particular, the forwarders used for biomass extraction have a much better floatation compared to the tractortrailer units, which allows stand access under wet soil conditions, as well as reduced soil compaction and stool damage. Furthermore, roadside chipping is best suited to building biomass stores, in the form of stacked tree sections at the roadside. As productivity is dependent on tree size, one could expect significant cost reductions if better clones are developed and/or rotations are further extended.

\section{References}

Ai J, Tschirner U (2010) Fiber length and pulping characteristics of switchgrass, alfalfa stems, hybrid poplar and willow biomasses. Bioresour Technol 101: 215-221.

Bedeneau M, Auclair D (1989) Effect of coppicing on hybrid poplar fine root dynamics. Ann For Sci 46 (suppl.): 294-296.

Björheden R, Apel K, Shiba M, Thompson M A (1995) IUFRO Forest work study nomenclature. Swedish University of Agricultural Science, Dept. of Operational Efficiency, Garpenberg. 16 p.

Ceulemans R, Deraedt W (1999) Production physiology and growth potential of poplars under short-rotation forestry culture. For Ecol Manag 121: 9-23.

Chiorescu S, Grönlund A (2001) Assessing the role of the harvester within the forestry-wood chain. For Prod J 51: 77-84.

Coleman M D, Isebrands J G, Tolsted D N, Tolbert V R (2004) Comparing Soil Carbon of Short Rotation Poplar Plantations with Agricultural Crops and Woodlots in North Central United States. Environ Manag 33: 299-308.

Djomo S N, Kasmioui O E, Ceulemans R (2011) Energy and greenhouse gas balance of bioenergy production from poplar and willow: a review. GCB Bioenerg 3: 181-197.

European Commission (Ed.). (2010) International Reference Life Cycle Data System Handbook: General guide for Life Cycle Assessment Detailed guidance. Author: Joint Research Center. 414p.

García S G, Berg S, Feijoo G, Moreira M T (2009) Environmental impacts of forest production and supply of pulpwood: Spanish and Swedish case studies. Int J Life Cycle Assess 14: 340 - 353.

Gellerstedt S, Dahlin B (1999) Cut-to-length: the next decade. J For Eng 10: $17-25$.

Guo L B, Gifford R M (2002) Soil carbon stocks and land use change: a meta analysis. Global Change Biol 8: 345-360.

Grosse W, Landgraf D, Scholz V, Brummack J (2008) Ernte und Aufbereitung von Plantagenholz (Harvesting and conditioning of wood from short-rotation plantations). Schweiz Z Forstwes 159: 114-119.

Helby P, Rosenqvist H, Roos A (2006) Retreat from Salix - Swedish experience with energy crops in the 1990s. Biomass Bioen 30: 422427.

Henderson D, Jose S (2010) Biomass production potential of three short rotation woody crop species under varying nitrogen and water availability. Agrofor Syst 80: 259-273.

Hillier J, Whittaker C, Dailey G, Aylott M, Casella E, Richter G M, Riche A, Murphy R, Taylor G, Smith P (2009) Greenhouse gas emissions from four bioenergy crops in England and Wales: Integrating spatial estimates of yield and soil carbon balance in life cycle analyses. GCB Bioenerg 1: 267-281.

Holtzscher M, Lanford B (1997) Tree diameter effects on cost and productivity of cut-to-length systems. For Prod J 47:25-30.

Hoogwijk M, Faaij A, Van der Broek R, Berndes G, Gielen D, Turkenburg W (2003) Exploration of the ranges of the global potential of biomass for energy. Biomass Bioen 25:119-133.

Jirjis R (2005) Effects of particle size and pile height on storage and 
fuel quality of comminuted Salix viminalis. Biomass Bioenerg 28 . 193-201.

Karacic J, Verwjist T, Weih M (2003) Above-ground woody biomass production of short rotation populus plantations on agricultural land in Sweden. Scand J For Res 18:427-437.

Kenney W, Sennerby-Forsse L, Layton P (1990) A review of biomass quality research relevant to the use of poplar and willow for energy conversion. Biomass 21: 163-188.

Londo M, Roos M, Dekker J, De Graaf H (2004) Willow short-rotation in multiple land-use systems: evaluation of four combination options in the Dutch context. Biomass Bioen 27: 205-221.

Manzone M, Airoldi G, Balsari P (2009) Energetic and economic evaluation of a poplar cultivation for the biomass production in Italy. Biomass Bioen 33: 1258-1264.

Nordh N E, Verwjist T (2004) Above-ground biomass assessments and first cutting cycle production in willow coppice. Biomass Bioen 27:1-8.

0’Neill M, Shock C, Lombard K, Heyduck R, Feibert E, Smeal D, Arnold R (2010) Hybrid poplar (Populus ssp.) selections for arid and semiarid intermountain regions of the western United States. Agrofor Syst 79: 409-418.

Pallardy S, Gibbins D, Rhoads J (2003) Biomass production by two-yearold poplar clones on floodplain sites in the Lower Midwest, USA. Agrofor Syst 59: 21-26.

Pellis A, Laureysens I, Ceulemans R (2004) Growth and production of a short rotation coppice culture of poplar I. Biomass Bioen 27:9-19.

Phelps J, Isebrands J, Einspahr D, Christ J, Sturos J (1985) Wood and paper properties of vacuum airlift segregated juvenile poplar whole-tree chips. Wood Fiber Sci 17: 529-539.

Proe M, Griffiths J, Craig J (2002) Effects of spacing, species and coppicing on leaf area, light interception and photosynthesis in short rotation forestry. Biomass Bioen 23: 315-326.

Rockwood DL, Naidu C, Carter D, Rahmani M, Spriggs T, Lin C, Alker G, Isebrands JG, Segrest S (2004) Short-rotation woody crops and phytoremediation: Opportunities for agroforestry? Agrofor Syst 6162: 51-63.

Rowe R L, Hanley M E, Goulson D, Clarke D J, Doncaster C P, Taylor G (2011) Potential benefits of commercial willow Short Rotation Coppice (SRC) for farm-scale plant and invertebrate communities in the agri-environment, Biomass Bioenerg 30: 325-336.

Sage R (19989 Short rotation coppice for energy: towards ecological guidelines. Biomass Bioen 15: 39-47.

Spinelli R, Owende P, Ward S, Tornero M (2003) Comparison of shortwood forwarding systems used in Iberia. Silva Fennica 38: 85-94.

Spinelli R, Hartsough B (2006) Harvesting SRF poplar for pulpwood:
Experience in the Pacific Northwest. Biomass Bioenerg 30: 439445.

Spinelli R, Nati C, Magagnotti N (2006) Biomass harvesting from buffer strips in Italy: three options compared. Agroforest Syst 68: 113-121.

Spinelli R, Hartsough B, Moore P (20089 Recovering sawlogs from pulpwood-size plantation cottonwood. For Prod J 58: 80-84.

Spinelli R, Visser R (2008) Analyzing and Estimating Delays in Harvester Operations. Int J For Eng 19: 35-40.

Spinelli R, Visser R (2009) Analyzing and estimating delays in wood chipping operations. Biomass Bioenerg 33: 429-433.

Spinelli R, Nati C, Magagnotti N (2009a) Using modified foragers to harvest short-rotation poplar plantations. Biomass Bioen 33: 817821.

Spinelli R, Ward S, Owende P (2009b) A harvest and transport cost model for Eucalyptus spp. fast-growing short rotation plantations. Biomass and Bioenerg 33: 1265-1270.

Spinelli R, Magagnotti N (2010) A tool for productivity and cost forecasting of decentralised wood chipping. For Pol Econ 12: 194-198.

Spinelli R, Magagnotti N, Picchi G, Lombardini C, Nati C (2011a) Upsized harvesting technology for coping with the new trends in short-rotation coppice. Appl Eng Agric 27: 1-7.

Spinelli R, Magagnotti N, Nati C (2011b) Work quality and veneer value recovery of mechanised and manual log-making in Italian poplar plantations. Eur J Forest Res 130:737-744.

Spinelli R, Ivorra L, Magagnotti N, Picchi G (2011c) Performance of a mobile mechanical screen to improve the commercial quality of wood chips for energy. Bioresour Technol 102, 7366-7370.

Tharakan P, Volk T, Abrahamson L, White E (2003) Energy feedstock characteristics of willow and hybrid poplar clones at harvest age. Biomass Bioenerg. 25: 571-580.

Tiernan D, Zeleke G, Owende P, Kanali C, Lyons J, Ward S (2004) Effect of Working Conditions on Forwarder Productivity in cut-to-length Timber Harvesting on Sensitive Forest Sites in Ireland. Biosyst Eng 87: 167-177.

Visser R, Stampfer K (2003) Tree-length system evaluation of second thinning in a loblolly pine plantation. South J Appl For 27: 77-82.

Weih M (2008) Short rotation forestry (SRF) on agricultural land and its possibilities for sustainable energy supply. Nordic Council of Ministers, TemaNord 2008: 543, Copenhagen, 66 p. Online: http://www.norden.org/en/publications/publications/2008-543.

Willebrand E, Ledin S, Verwijst T (1993) Willow coppice systems in short rotation forestry: effects of plant spacing, rotation length and clonal composition on biomass production. Biomass En. 4: 323-331. 